\title{
ANALISIS LOW EXTERNAL INPUT SUSTAINABLE AGRICULTURE (LEISA) PADA TERNAK DOMBA DI KAWASAN AGRIBISNIS DESA TERNAK, DESA CINTALAKSANA KECAMATAN TEGALWARU, KABUPATEN KARAWANG
}

\section{ANALYSIS OF LOW EXTERNAL INPUT SUSTAINABLE AGRICULTURE (LEISA) IN AGRIBISNIS LIVESTOCK ZONE AT CINTALAKSANA VILLAGE, TEGALWARU SUBDISTRICT, KARAWANG DISTRICT}

\author{
Achmad Firman $^{1 *}$, Linda Herlina ${ }^{1}$, Slamet Yulianto ${ }^{2}$ \\ ${ }^{1}$ Departemen Sosial dan Ekonomi Pembangunan Peternakan, Fakultas Peternakan, \\ Universitas Padjadjaran, Jl. Raya Bandung Sumedang Km 21, Jatinangor Sumedang \\ ${ }^{2}$ Dinas Pertanian Kabupaten Karawang, Jl. By pass Tanjungpura, Tanjung Mekar, \\ Karawang Barat, Kabupaten Karawang \\ *Corresponding email: ahmadpedum@yahoo.com \\ (Diterima 12-12-2018; Disetujui 15-01-2019)
}

\begin{abstract}
ABSTRAK
Penelitian ini bertujuan untuk menganalisis kemampuan wilayah di kawasan agribisnis di Desa Cintalaksana untuk menampung ternak domba melalui konsep Low External Input Sustainable Agriculture (LEISA). Desa Cintalaksana didominasi oleh hutan dan sawah sehingga diperkirakan desa ini dapat dikembangkan untuk pengembangan ternak domba. Hasil analisis menunjukkan bahwa ketersediaan hijauan yang mampu dihasilkan oleh Desa Cintalaksana adalah 4.316,93 ton bahan kering per tahun. Adapun kapasitas tampung ternak domba yang dapat dikembangkan adalah 29.563 satuan ternak. Hasil analisis indeks daya dukung (IDD) atas wilayah tersebut menunjukkan IDD - 1,0002, yang artinya nilai tersebut masuk dalam wilayah kritis. Jadi pengembangan ternak domba dengan konsep LEISA karena nilai indexnya menunjukkan angka kritis.
\end{abstract}

Kata Kunci: Pengembangan, Domba, Daya Dukung

\begin{abstract}
The purpose of the research is to analyze regional carrying capacity to keep sheep in agribusiness zone at Cintalaksana village through the concept of Low External Input Sustainable Agriculture (LEISA). The village is dominated by forest and paddy land that indicate forage availabality to develop sheep commodity. The result research showed that forage availability that can be produced approaximately 4.316,93 ton dry matter per year. The amount of sheep can be kept approaximately 29.563 animal units. The analysis of carrying capacity index showed that Cintalaksana village had the carrying capacity index is 1,0002 which means that the value is in a critical category. Therefore the sheep development in Desa Cintalaksana could not support to LEISA concept because the index value is a critical category.
\end{abstract}

Keywords: Develeopment, Sheep, Carrying Capacity

\section{PENDAHULUAN}

Low external input sustainable agriculture telah menjadi isu yang penting di negara-negara Eropa sejak tahun 1994. Teori ini muncul didasarkan pada revolusi hijau yang menitikberatkan pada keberlanjutan usaha pertanian melalui pemanfaatan input sebesar-besarnya yang dihasilkan di suatu wilayah dengan meminimalisasi penggunaan input dari luar wilayah (Kesseler and Moolhulizen, 1994). Dengan demikian, LEISA adalah suatu 
program dalam rangka pemanfaatan sumber daya internal semaksimal mungkin dengan mengurangi penggunaan input-input yang berasal dari luar wilayah. Program ini ditujukan dalam rangka pengurangan biaya input, mengurangi ketergantungan input luar, dan mencegah dampak negatif dari masuknya input luar, seperti penyakit.

Hasil penelitian LEISA yang dilakukan oleh Kesseler and Moolhulizen (1994) di Philiphina dan Ghana menunjukkan bahwa di wilayah yang memiliki potensi produksi pertanian tinggi, LEISA secara simultan dari sisi sosial ekonomi meningkat dengan mengurangi pemanfaatan input dari luar wilayah dan mampu memperbaiki lingkungan ekologi secara berkelanjutan. Sebaliknya, pada wilayah yang produksinya rendah (low production), LEISA dapat menstabilkan dan mengembalikan carrying capacity, tetapi memiliki keterbatasan potensi untuk meningkatkan kondisi sosial ekonomi karena penggunaan external input yang banyak.

Keberlanjutan pertanian lebih didorong pada kemampuan wilayah menghasilkan sumber pangan ataupun pakan. Konsep LEISA sangat erat hubungannya dengan keberlanjutan pertanian. Menurut Tanh (1996) menyatakan bahwa kosep LEISA menititkberatkan pada: (1) mengoptimalkan penggunaan sumber daya yang tersedia secara lokal, sehingga mencapai efek sinergis di antara berbagai komponen sistem pertanian (tanah, air, hewan, tumbuhan, dan lain-lain) sehingga mereka saling melengkapi dalam produksi output; dan (2) Meminimalkan penggunaan input eksternal, kecuali jika ada defisiensi yang serius dan di mana efeknya pada sistem akan meningkatkan daur ulang nutrisi. Tujuan dari LEISA ini adalah bukan untuk memaksimalkan produksi jangka pendek, tetapi untuk mencapai tingkat yang memadai dan berkelanjutan dalam jangka panjang.

Penggunaan LEISA akan diterapkan di kawasan agribisnis "Desa Ternak" di Desa Cintalaksana, Kecamatan Tegalwaru, Kabupaten Karawang. Desa Ternak adalah desa yang berbasiskan sumber daya ternak lokal potensial, yaitu domba di mana melalui pengembangan ternak domba di wilayah ini dapat meningkatkan nilai tambah pendapatan bagi petani serta mampu menjaga kelestarian lingkungan (Dinas Pertanian Kabupaten Karawang, 2017).

Kabupaten Karawang menjadi salah satu lumbung padi nasional karena produksi padi di wilayah ini cukup besar. Walaupun tingkat alih fungsi lahan di kabupaten ini 
cukup tinggi, namun produktivitas padinya cukup baik. Potensi yang dapat dimanfaatkan dari tanaman padi adalah limbahnya. Hasil pengolahan padi adalah beras yang menghasilkan dedak yang dapat dimanfaatkan untuk pakan ternak. Sedangkan hasil limbah dari pemotongan padi adalah berupa jerami padi yang juga dapat dimanfaatkan untuk pakan ternak juga. Potensi-potensi tersebut dapat dimanfaatkan untuk peningkatan populasi ternak ruminansia, khususnya domba.

Domba merupakan komoditas yang sudah sejak lama menjadi peliharaan para petani padi di Jawa Barat. Ternak domba menjadi usaha sampingan bagi petani pedesaan karena komoditas ini bisa menjadi penyangga bagi kehidupan petani. Ternak ini sewaktu-waktu dapat dijual untuk memenuhi kebutuhan rumah tangga petani tersebut, baik untuk biaya sekolah, kesehatan, pernikahan, khitanan, dan sebagainya (Firman, dkk., 2018).

Ada berbagai jenis domba yang ada di Jawa Barat, yaitu domba Priangan dan domba Garut. Domba Priangan adalah termasuk dalam kategori domba ekor tipis (DET) di mana domba-domba ini banyak dipelihara oleh masyarakat pertanian pada umumnya, sedangkan domba Garut termasuk dalam kategori domba ekor gemuk (DEG) yang cenderung dipelihara oleh masyarakat penggemar domba adu ((Williamson dan Payne, 1993. Sumoprastowo, 1987).

Ternak domba memiliki kemampuan berkembang dan beradaptasi di semua zona agroekologi (karenanya ternak domba menyebar hampir di seluruh wilayah Indonesia), mampu memanfaatkan hijauan yang nilai nutrisinya rendah, tahan terhadap penyakit dan parasit, mampu beranak lebih dari satu (prolific), umur dewasa kelamin relatif cepat, serta tidak mengenal musim kawin (FAO, 2002; Jarmuji, 2010; Firman, dkk., 2018).

Penggunaan konsep LEISA kawasan agribisnis "Desa Ternak" dikhususkan pada pemanfaatan sumber-sumber pakan domba yang terdapat di wilayah tersebut dan sekitarnya. Potensi pakan hijuan dan limbah pertanian yang cukup tersedia di wilayah tersebut diduga dapat memenuhi kebutuhan pakan domba di Desa Ternak tersebut. Tersedianya pakan di wilayah tersebut dapat mengurangi biaya pakan yang besarnya dapat mencapai $60-70 \%$ dari total biaya produksi. Dengan demikian, program LEISA menjadi penting dilakukan di kawasan agribisnis Desa Ternak tersebut. Model LEISA yang didekati dengan kapasitas daya tampung adalah konsep yang mengedepankan keberlanjutan sumber daya pakan bagi ternak domba. Daya 
tampung wilayah menunjukkan besarnya kemampuan lingkungan untuk mendukung kehidupan hewan dari suatu spesies, yang dinyatakan dalam jumlah ekor persatuan jumlah lahan (Soemarwoto, 1983; Ma'sum, 1999).

Di samping itu, konsep pengembangan domba di Desa Ternak ini melibatkan partisipasi masyarakat yang dikemas dalam bentuk pemberdayaan masyarakat. Masyarakat desa tersebut nantinya akan dilibatkan dalam pengembangbiakan domba, terutama ternak bibit. Hal ini telah sesuai dengan amanah Undang-undang No. 41 Tahun 2014 tentang Perubahan atas Undang-undang No. 18 Tahun 2009 tentang Peternakan dan Kesehatan Hewan pasal 13 ayat 1 yang menyatakan bahwa Pemerintah dan/atau Pemerintah Daerah sesuai dengan kewenangannya berkewajiban untuk melakukan pemuliaan, pengembangan usaha pembenihan dan/atau pembibitan dengan melibatkan peran serta masyarakat untuk menjamin ketersediaan benih dan/atau bibit. Oleh karena itu, fokus dari pemberdayaan masyarakat di sini adalah keterlibatan masyarakat desa dalam pengembangbiakan bibit ternak, khususnya domba yang nantinya diproduksi oleh unit pelaksana teknis daerah.
Oleh karena itu, tujuan dari penelitian ini adalah untuk menganalisis jumlah pakan hijauan yang tersedia dan kemampuan wilayah dalam menampung jumlah domba di kawasan agribisnis "Desa Ternak" di Desa Cintalaksana, Kecamatan Tegalwaru, Kabupaten Karawang.

\section{METODE PENELITIAN}

Objek penelitian yang digunakan dalam penelitian ini adalah data-data yang terkait dengan penentuan indeks daya tampung (IDD) ternak domba di Desa Cintalaksana, Kecamatan Tegalwaru, Kabupaten Karawang.

Metode yang digunakan dalam penelitian ini adalah metode kuantitatif di mana hasil dari penelitian ini dideskripsikan untuk menjelaskan hasilhasil analisis dari data dan informasi yang diperoleh.

Data yang dikumpulkan adalah data sekunder yang diperoleh dari Dinas Pertanian Kabupaten Karawang, BPS Kabupaten Karawang, Kantor Desa Cintalaksana, dan data lainnya yang terkait dengan penelitian.

Metode analisis yang digunakan dalam penelitian ini adalah indeks daya dukung dengan tahapan analisis sebagai berikut:

a. Analisis kebutuhan pakan hijauan minimum untuk ternak ruminansia kecil 
adalah $\mathrm{KH}=4 \% \times 50 \% \times 365 \times 20 \mathrm{Kg}=$ 0,146 ton $\mathrm{BK} / \mathrm{tahun} / \mathrm{ST}$.

Dimana $\mathrm{K}=$ Kebutuhan pakan minimum untuk 1 ST dalam ton bahan kering tercerna atau DDM (digesible dry matter) selama satu tahun (Thahar et al, 2003 yang dikutip oleh Juarini et al, 2011).

b. Analisis Potensi Pakan. Khusus untuk pakan domba, pakan hijauan yang dapat dimanfaatkan adalah rumput yang diperoleh dari hasil identifikasi lahan sebagai berikut (Thahar et al, 2003 yang dikutip oleh Juarini et al, 2011):

- Lahan sawah $=(0,2832 \times$ luas lahan) ton BK/tahun

- Lahan Kering $=(6,3212 \quad \mathrm{x}$ luas lahan) ton $\mathrm{BK} /$ tahun

- Lahan Pangonan $=(6,4601 \times$ luas lahan) ton BK/tahun

- Lahan Hutan $=(6,3894 \times$ luas lahan) ton $\mathrm{BK} /$ tahun

c. Daya Tampung Ternak dianalisis dari Daya Dukung Hijauan, diukur dari ketersediaan rumput untuk kebutuhan minimal dari domba dengan formula sebagai berikut (Silaban et al, 2015):

$$
\mathrm{WK}_{\mathrm{j}}=\frac{\sum_{i=1}^{n=4} L_{i} R_{i}}{K H}-0,065\left(Y_{d b}\right)
$$

Dimana:

WK adalah kemampuan wilayah kecamatan ke-j menampung satuan ternak kecil

KH adalah kebutuhan hijauan setiap ST per tahun $(0,146$ ton $\mathrm{BK} /$ tahun $)$

$\mathrm{L}_{\mathrm{i}} \quad$ adalah luas masing-masing jenis ekologi lahan $(i=1,2,3,4)$

$\mathrm{R}_{\mathrm{i}}$ adalah produktivitas rumput dari setiap jenis ekologi lahan per tahun $\mathrm{Y}_{\mathrm{db}}$ adalah populasi domba (satuan ekor). Nilai 0,065 adalah nilai konversi populasi ternak domba ke satuan ternak (ST)

d. Indeks Daya Dukung (IDD) hijauan ternak domba dihitung berdasarkan bahan kering dengan persamaan sebagai berikut (Ashari et al, 2003 yang dikutip oleh Juarini et al, 2011). Indeks ini dihitung berdasarkan formula berikut, yaitu Total Produksi Bahan Kering (BK)/(Jumlah populasi ternak ruminansia dengan formula (ST) $\mathrm{x}$ Kebutuhan BK domba dewasa $(\mathrm{Kg} / \mathrm{ST}))$.

Adapun kriteria status daya dukung hijauan berdasarkan indeks daya dukung diuraikan sebagai berikut:

- IDD $>2=\operatorname{aman}$

- IDD $>1,5-2$ = rawan

- IDD $>1-1,5=$ kritis

- $\operatorname{IDD}<1=$ sangat kritis 


\section{HASIL DAN PEMBAHASAN}

\subsection{Gambaran Umum}

Secara geografis, Desa Cintalaksana merupakan ibukota Kecamatan Tegalwaru Kabupaten Karawang. Letak Astronomis Desa Cintalaksana berada di $-6.57054{ }^{\circ} \mathrm{LS}$ - 107.20357 ${ }^{\circ} \mathrm{BT}$ dengan ketinggian 104,2 meter dpl. Luas wilayah Desa Cintalaksan aadalah $8,46 \mathrm{~km}^{2}$ (846 ha) atau $9.7 \%$ dari total luas Kecamatan Tegalwaru. Desa Cintalaksana memiliki 4 dusun, 4 RW, dan 11 RT. Topografi wilayah Desa Cintalaksana sebagian berbukit-bukit, dataran tinggi, lereng gunung, dilewati aliran sungai/bantaran sungai. Letaknya dekat/berada di kawasan hutan dan wisata. Dengan karakteristik wilayah demikian, suhu rata-rata harian $20-45^{\circ} \mathrm{C}$. Curah hujan di Desa Cintalaksana adalah 2.600-4.500 mm dengan jumlah bulan hujan sebanyak 4 bulan dalam satu tahun.

Berdasarkan profil Desa Cintalaksana tahun 2017, luas lahan yang dimanfaatkan untuk sawah $1 / 2$ irigasi teknis hampir mencapai 20\% dari total luas lahan (Tabel 1). Sedangkan lahan yang digunakan untuk perkebunan dan hutan hampir mencapai 80\% dari luas lahan Desa Cintalaksana. Adapun pemanfaatan lahan-lahan untuk keperluan lainnya masih di bawah $1 \%$. Data ini memberikan informasi bahwa pertanian dan kehutanan menjadi lahan yang mendominasi wilayah Desa Cintalaksana.
Tabel 1. Pemanfaatan Lahan di Desa Cintalaksana

\begin{tabular}{lcc}
\hline \multicolumn{1}{c}{ Penggunaan } & $\begin{array}{c}\text { Luas Lahan } \\
\text { (ha) }\end{array}$ & \% \\
\hline Sawah Irigasi 1/2 teknis & 168 & 19.86 \\
\& Sawah Tadah Hujan & & \\
Perkebunan/Hutan & 668 & 78.96 \\
Tanah Tegal/Ladang & 0.5 & 0.06 \\
Pemukiman & 5.8 & 0.69 \\
Pekarangan & 0.5 & 0.06 \\
Perkantoran & 1.5 & 0.18 \\
Prasarana Umum & 1 & 0.12 \\
\hline Total Luas & 846 & \\
\hline Sumber: Profil Desa Cintalaksana, 2017
\end{tabular}

Lahan permukiman hanya menduduki peringkat ketiga dalam hal pemanfaatan lahan dengan luasan 5,8 ha. Hal ini menunjukkan bahwa alih fungsi lahan pertanian ke pemanfaatan lain relatif masih kecil.

Tabel 2 memperlihatkan populasi ternak yang ada di Desa Cintalaksana. Populasi terbesar didominasi oleh unggas (ayam kampung, ayam ras, dan bebek), sedangkan ruminansia masing-masing kurang dari 100 ekor. Domba yang menjadi target pengembangan hanya berjumlah 70 ekor. Jika dilakukan perhitungan, dengan asumsi setiap domba mengonsumsi $4 \mathrm{~kg}$ hijauan per ekor per hari, maka kebutuhan pakan hijauan untuk 70 ekor domba adalah $280 \mathrm{~kg} /$ hari (2,8 ton/10 hari). 
Tabel 2. Populasi Ternak di Desa Cintalaksana Kecamatan Tegalwaru (2017)

\begin{tabular}{lc}
\hline \multicolumn{1}{c}{ Jenis Ternak } & $\begin{array}{c}\text { Jumlah Populasi } \\
\text { (Ekor) }\end{array}$ \\
\hline Sapi & 30 \\
Kerbau & 2 \\
Kambing & 30 \\
Domba & 70 \\
Ayam Kampung/Buras & 1000 \\
Ayam Pedaging/Ras & 500 \\
Bebek & 500 \\
\hline Sumber: Profil Desa Cintalaksana, 2017
\end{tabular}

\subsection{Analisis Ketersediaan Hijauan}

Hijauan makan ternak menjadi pakan utama ternak ruminansia, khususnya domba. Pemberian pakan yang tidak kontinu dapat menimbulkan sterss dan akan berakibat peka terhadap berbagai penyakit dan terganggu pertumbuhannya (Ahmad et al, 2004). Hijauan makanan ternak yang dipergunakan untuk ternak ruminansia sebagian besar rumput-rumputan, sehingga rumput memegang peranan penting dalam proses budidayanya (Sofyan, 2003).

Desa Cintalaksana didominasi oleh hutan dan perkebunan atau seluas $80 \%$ dati total wilayah. Hal ini memberikan potensi cukup baik untuk sumbangan hijauan pakan ternak. Hasil hitungan potensi hijauan makanan ternak (HMT) dari penggunaan lahan-lahan yang ada, seperti terlihat pada Tabel 3.
Tabel 3. Potensi Hijauan (ton Bahan Kering per Tahun

\begin{tabular}{lcc}
\hline \multicolumn{1}{c}{ Penggunaan } & $\begin{array}{c}\text { Luas } \\
\text { Lahan } \\
\text { (ha) }\end{array}$ & $\begin{array}{c}\text { Potensi } \\
\text { Hijauan } \\
\text { (ton BK/tahun) }\end{array}$ \\
\hline $\begin{array}{l}\text { Sawah Irigasi } 1 / 2 \\
\text { teknis \& Sawah } \\
\text { Tadah Hujan }\end{array}$ & 168 & 45,58 \\
\hline Perkebunan/Hutan & 668 & $4.268,12$ \\
\hline $\begin{array}{l}\text { Tanah } \\
\text { Tegal/Ladang }\end{array}$ & 0,5 & 3,23 \\
\hline Pemukiman & 5,8 & 0 \\
\hline Pekarangan & 0,5 & 0 \\
\hline Perkantoran & 1.5 & 0 \\
\hline Prasarana Umum & 1 & 0 \\
\hline Total Luas & 846 & $4.316,93$ \\
\hline
\end{tabular}

Berdasarkan Tabel 3, potensi HMT yang bisa dimanfaatkan dari lahan-lahan yang dimiliki oleh Desa Cintalaksana sebesar 4.317 ton bahan kering pertahun. Potensi hijauan ini menjadi titik awal perhitungan berapa jumlah ternak ruminansia kecil, seperti domba, dapat ditampung di desa ini.

\subsection{Analisis Daya Dukung}

Populasi ternak ruminansia yang ada sebagaimana telah diungkapkan sebelumnya dikonversi ke dalam satuan ternak (ST) seperti terlihat pada Tabel 4. Berdasarkan hasil konversi tersebut, jumlah populasi ternak ruminansia sebanyak 31,9 satuan ternak, termasuk di dalamnya adalah domba (4.5 satuan ternak). Konversi ini dijadikan dasar untuk perhitungan kapasitas tampung ternak domba. 
Ternak domba merupakan ternak ruminansia terbanyak di Desa Cintalaksana disusul oleh ternak sapi dan kambing. Akan tetapi, jika populasi ternak ruminansia tersebut dihitung dalam satuan ternak, maka ternak sapi yang terbanyak dari sisi satuan ternak. Nilai satuan ternak ini diperlukan untuk menghitung daya tampung ternak yang dapat ditampung di desa tersebut.

Tabel 4. Populasi Ternak Ruminansia di Desa Cintalaksana dalam Satuan Ternak

\begin{tabular}{lccc}
\hline \multirow{2}{*}{ Jenis Ternak } & \multicolumn{2}{c}{ Jumlah Populasi } & \multirow{2}{*}{$\%$} \\
\cline { 2 - 3 } & (Ekor) & ST & \\
\hline $\begin{array}{l}\text { Ruminansia } \\
\text { Besar }\end{array}$ & & 25.4 & \\
\hline Sapi & 30 & 24 & 75.2 \\
Kerbau & 2 & 1.4 & 4.4 \\
\hline Ruminansia & & 6.5 & \\
Kecil & & & \\
\hline Kambing & 30 & 1.95 & 6.1 \\
Domba & 70 & 4.55 & 14.3 \\
\hline Total & & $\mathbf{3 1 . 9}$ & \\
\hline
\end{tabular}

Atas dasar perhitungan dari Tabel 3 dan 4 dapat dianalisis jumlah kapasitas tampung wilayah untuk ternak domba di Desa Cintalaksana. Hasil analisis juga memperlihatkan jumlah ternak domba adalah sebanyak 29.563 ST yang diperoleh dari formula sebagai berikut:

$$
\begin{aligned}
\mathrm{WK} & =(4.316,93 / 0.146)-(0.065 \times 70 \text { ekor }) \\
& =29.563 \mathrm{ST}
\end{aligned}
$$

Berdasarkan kapasitas tampung ternak tersebut dapat dihitung nilai indek daya tampung (IDD) untuk ternak domba.
Adapun indek ini dihitung berdasarkan jumlah bahan kering dibagi dengan total populasi dikali dengan total kebutuhannya. Apabila seluruh hijauan yang ada disediakan untuk ternak domba, maka indek daya dukungnya adalah sebagai berikut:

1. Total bahan kering hijauan yang mamapu disediakan adalah sebanyak 4.316,93 ton BK/hijauan/tahun.

2. Kebutuhan pakan hijauan ternak domba adalah 0,146 ton $\mathrm{BK} /$ tahun/ST.

3. Total populasi domba adalah 29.563 ST

Berdasarkan formulasi pada bagian metode analisis, maka dapat dihitung nilai IDD adalah sebagai berikut:

IDD $=(4.316,93$ ton BK/hijauan/tahun $) /$ (29.563 ST $\mathrm{x} \quad 0,146$ ton BK/ekor domba/tahun) hasilnya adalah 1,0002 .

Apabila wilayah dengan nilai IDD $=$ 1,0002. Nilai IDD sebesar itu berada di wilayah IDD $1-1,5$, yang artinya adalah wilayah kritis.

Hasil analisis di atas dapat membuktikan bahwa kemampuan wilayah untuk menampung ternak domba di Desa Cintalaksana adalah kritis. Ini berarti bahwa pengembangan ternak domba di Desa Cintalaksana dengan menggunakan konsep LEISA tidak dapat berjalan karena sumber daya dukung pakan hijauan di desa tersebut tidak mampu untuk memenuhi 
kebutuhan domba. Hal ini menunjukkan bahwa apabila ternak domba dikembangkan di Desa Cintalaksana, maka akan mendatangkan sumber pakan dari wilayah lain untuk memenuhi kebutuhannya.

Dasman (1964) membedakan tiga pengertian daya tampung, yaitu:

1. Pengertian daya tampung yang berhubungan dengan kurva logistik, dimana daya tampung adalah asimtot atas dari kurva tersebut. Dalam hal ini batasan daya tampung adalah batasan teratas dari pertumbuhan populasi dimana pertumbuhan populasi tidak dapat didukung lagi oleh sumberdaya dan lingkungan yang ada,

2. Pengertian daya tampung yang dikenal dalam pengelolaan margasatwa. Dalam hal ini daya tampung adalah jumlah individu yang dapat didukung oleh suatu habitat;

3. Pengertian daya tampung yag dikenal dalam pengelolaan padang penggembalaan. Dalam hal ini daya tampung adalah jumlah individu yang dapat didukung oleh lingkungan dalam keadaan sehat tanpa mengganggu kerusakan tanah. Tingkat ketersediaan hijauan makanan ternak pada suatu wilayah merupakan salah satu faktor yang sangat penting serta turut mempengaruhi dinamika populasi dalam keberhasilan pengembangan ternak, khususnya ternak herbivora.

\section{KESIMPULAN}

Berdasarkan hasil analisis menunjukkan sebagai berikut:

1. Jumlah hijauan dalam bentuk bahan kering yang dapat disediakan untuk ternak domba adalah 4.316,93 ton BK/hijauan/tahun.

2. Ternak domba yang dapat dihasilkan adalah 29.563 satuan ternak.

3. Nilai Indeks Daya Dukung (IDD) untuk Desa Cintalaksana masuk kategori krisis.

4. Hasil ini memberikan jawaban bahwa konsep LEISA di Desa Cintalaksana tidak dapat dikembangkan.

\section{UCAPAN TERIMA KASIH}

Kami ucapkan terima kasih kepada Dinas Pertanian Kabupaten Karawang atas kerjasama penelian ini di mana pihak dinas memberikan dukungan finansial atas penelitian ini.

\section{DAFTAR PUSTAKA}

Ahmad, S.N., Siswansyah, D.D dan Swastika, D.K.S. 2004. Kajian Sistem Usaha Ternak Sapi Potong di Kalimantan Tengah. Jurnal Pengkajian dan Pengembangan Teknologi Pertanian, 7(2): 155-170. 
Benny, Guido. 2002. Sap 2 Evaluasi Proyek: Pengertian Evaluasi Proyek, Aspek-Aspeknya dan Metode Memperoleh Gagasan. Jakarta: Universitas Indonesia.

Dasman, R.F., 1964. Wildslife Biology. J. Wiley and Son.Inc. New York.

Dinas Pertanian Kabupaten Karawang. 2017. Studi Kelayakan Desa Ternak di Desa Cintalaksana, Kecamatan Tegalwaru, Kabupaten Karawang. Dinas Pertanian Kabupaten Karawang. Karawang.

Firman, A., Herlina L, Paturochman M, dan Sulaeman, MM. 2018. Penentuan Kawasan Unggulan Agribisnis Ternak Domba di Jawa Barat. Jurnal Pemikiran Masyarakat Ilmiah Berwawasan Agribisnis, 4(1): 111125.

Food and Agriculture Organization (FAO). 2002. Conserving and Developing Farm Animal Diversity. Rome: Secretariat of The Report on The State of The Word's Animal Genetic Resources. FAO. Roma.

Jarmuji. 2010. Produksi Susu Induk Terhadap Pengaruh Pertambahan Bobot Badan, Bobot Sapih Dan Daya Hidup Anak Domba Ekor Tipis Jawa Periode Prasapih. Jurnal Sain Peternakan Indonesia, 5(1): 34-42.

Juarini, E, Sumanto, Wibowo B, Suratman. 2011. Daya Dukung Hijauan Pakan untuk Pengembangan Ternak Sapi Potong dan Kerbau dalam Mendukung PSDS/K Tahun 2014 di Kabupaten Lebak. Seminar Nasional Teknologi Peternakan dan Veteriner. Pusat Penelitian dan Pengembangan Peternakan. Kementerian Pertanian. Bogor (Indonesia): Penelitian dan Pengembangan Peternakan.
Kesseler, J.J, and Moolhulizen M. 1994. Low External Input Sustainable Agriculture: Expectations and Realities. Netherlands Journal of Agriculture Science, 42 (3): 181-194.

Ma'sum, M., 1999. Kemungkinan Pengunaan Data Satelit untuk Mengestimasi Produksi Pakan Ruminansia. Badan Penelitian dan Pengembangan Pertanian. Deptan. Bogor.

Sofyan, I., 2003. Kajian Pengembangan Bisnis Pengusahaan Kebun Rumput Gajah untuk Penyediaan Pakan pada Usaha Penggemukan Sapi Potong PD. Gembala Kabupaten Garut Jawa Barat. Program Studi Manajemen Agribisnis, Fakultas Pertanian. IPB.

Soemarwoto, I., 1983. Pengelolaan Sumberdaya Alam. Bagian II. Sekolah Pasca Sarjana. Jurusan pengelolaan Sumberdaya Alam dan Lingkungan. IPB.

Sumoprastowo, R.M. 1987. Beternak Domba Pedaging dan Wol. Bogor: Departemen Ilmu Makanan Ternak, IPB.

Thanh, D.N. 1996. Low External Input Sustainable Agriculture (LEISA) in Selected Countries of Asia. Regional Office for Asia and the Pacific (RAP) Publication: 1996/19.

Williamson, G. dan W.J.A. Payne, 1993. Pengantar Peternakan di Daerah Tropis. Universitas Gadjah Mada, Yogyakarta. 